\title{
Contagion of fear: Is the impact of COVID-19 on sovereign risk really indiscriminate?
}

\author{
Serhan Cevik ${ }^{1}$ (D) | Belma Öztürkkal ${ }^{2}$ (])
}

\footnotetext{
${ }^{1}$ Western Hemisphere Department, International Monetary Fund, Washington, District of Columbia, USA

${ }^{2}$ Department of International Trade and Finance, Kadir Has University, Istanbul, Turkey

\section{Correspondence}

Serhan Cevik, Western Hemisphere Department, International Monetary Fund, 700 19th St, NW, Washington, DC 20431, USA.

Email: scevik@imf.org
}

\begin{abstract}
This paper investigates the impact of infectious diseases on the evolution of sovereign credit default swap (CDS) spreads for a panel of 77 countries. Using annual data over 2004-2020, we find that infectious-disease outbreaks have no discernible effect on CDS spreads, after controlling for macroeconomic and institutional factors. However, a granular analysis using highfrequency data indicates that the COVID-19 pandemic has had a significant impact on CDS spreads. This adverse effect appears to be more pronounced in advanced economies, which may reflect the greater severity of the pandemic and depth of the economic crisis in these countries, at least during the initial stage of the outbreak, as well as underreporting in developing countries due to differences in testing availability and institutional capacity. While more stringent containment measures help lower sovereign CDS spreads, the fiscal burden of these efforts could undermine credit worthiness and eventually push the cost of borrowing higher.
\end{abstract}

\section{K E Y W O R D S}

CDS spreads, COVID-19, infectious diseases, sovereign credit risk

JEL CLASS I F I C A T I O N

F34, G12, G13, G15 


\section{I INTRODUCTION}

The COVID-19 pandemic has caused an unprecedented macrofinancial shock and severely strained public finances across the world. As of July 12, 2021, there are over 187 million confirmed cases of COVID-19 in 190 countries, with more than 4 million deaths. ${ }^{1}$ To contain the pandemic and protect susceptible populations, most countries imposed stringent lockdown measures that have led to a contraction in economic activity unparalleled since the Great Depression in the 1930s. Weaker economic conditions, heightened risk aversion, and uncertainty surrounding the pandemic's evolution have led to a surge in credit default swap (CDS) spreads-a market-implied indicator of sovereign credit quality and default risk. On average, the cost of insuring against sovereign default risk over 5 years increased by as much as 39 basis points for advanced economies and 770 basis points for developing countries in the first half of 2020 (Figure 1).

The economic fallout from the COVID-19 pandemic has undermined public finances across the globe, but is this really an indiscriminate shock? We think not. It is true that the deep contraction in economic activity and ensuing fall in government revenues, along with a significant increase in expenditures, have led to a surge in budget deficits and public debt. According to the latest Indian Monetary Funds (IMF) projections, government debt reached an all-time high, exceeding 100 percent of gross domestic product (GDP) in 2020-an increase of almost 20 percentage points from a year ago. Nevertheless, there is still significant heterogeneity in how the pandemic has affected sovereign default risk across countries. The empirical analysis presented in this paper shows that the change in CDS spreads depends on initial macroeconomic and financial conditions, the extent of exposure to the COVID-19 pandemic, and policy responses aimed at cushioning the shock.

The CDS market has grown rapidly over the past two decades to become one of the main financial instruments to manage credit risk. Conceptually, CDS function like insurance contracts: the buyer of CDS has the right to sell a given bond, issued by a sovereign (or a corporate, for that matter), to the seller of CDS at par upon the occurrence of a credit event (i.e., default), as specified in the contract (Hull et al., 2004). For such insurance coverage, the buyer pays a premium-known as the CDS spread-to the seller. ${ }^{2}$ There is a large body of literature on the macroeconomic and institutional determinants of sovereign CDS spreads as a marketdetermined indicator of default risk. However, there is nascent research looking at how the spread of infectious diseases affects CDS spreads and, in particular, the factors explaining heterogeneity in impact across countries. Accordingly, our empirical objectives in this paper are threefold: (i) ascertaining the conventional macroeconomic and institutional determinants of sovereign CDS spreads using a standard model with fixed effects; (ii) augmenting the baseline model to investigate the impact of infectious diseases on sovereign CDS spreads; and (iii) developing a more granular analysis to focus on the COVID-19 pandemic by estimating the regression model with high-frequency (daily) data.

With a large data set of annual observations covering 77 advanced and developing countries, we find that past epidemics had no significant effect on sovereign CDS spreads, after controlling for macroeconomic, financial, and institutional factors. ${ }^{3}$ Even so, there is still evidence of significant heterogeneity in how past infectious-diseases episodes affect CDS spreads across countries. The magnitude of this effect varies with macroeconomic conditions and institutional strength, which may in turn help determine the effectiveness of policy response to infectious disease outbreaks. This is why we develop a more granular analysis to focus exclusively on the impact of COVID-19 with high-frequency (daily) data covering 77 countries and territories 


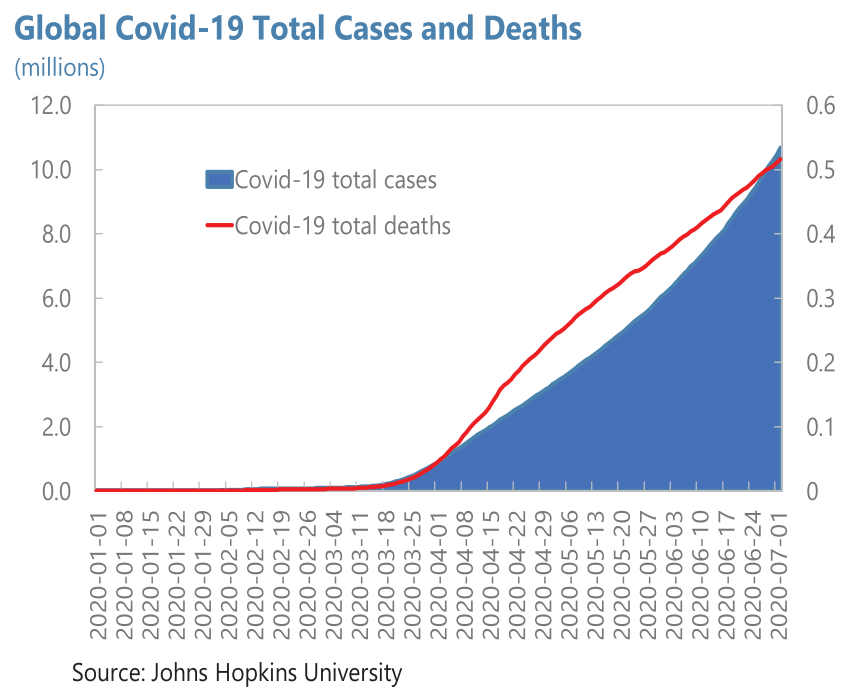

\section{5-year CDS Spreads}

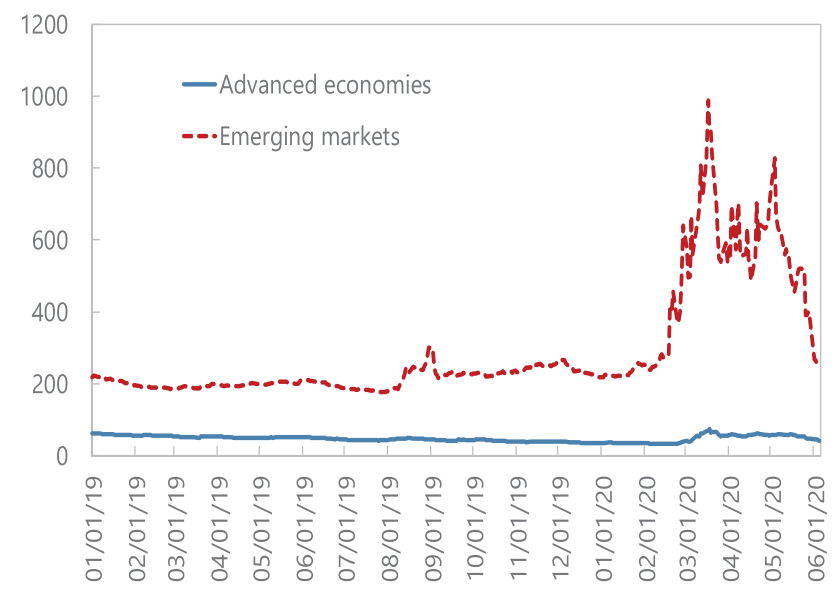

Source: Bloomberg

F I G U RE 1 COVID-19 and sovereign CDS spreads. CDS, credit default swap [Color figure can be viewed at wileyonlinelibrary.com]

during the first half of 2020. These results indicate that the COVID-19 pandemic has had a significant impact on sovereign CDS spreads across all countries. This adverse effect is found to be more pronounced in advanced economies, which may reflect the greater severity of the pandemic and depth of the ensuing economic crisis in these countries, at least during the initial stage of the outbreak, as well as underreporting in developing countries due to differences in testing availability and institutional capacity. Our empirical analysis also shows that more stringent domestic containment measures help lower sovereign CDS spreads, but the macrofiscal burden of these efforts could undermine credit worthiness and eventually push the cost of borrowing higher. 
The remainder of this study is organized as follows. Section 2 provides a brief overview of the related literature. Section 3 describes the data used in the analysis. Section 4 introduces the salient features of our econometric strategy and presents the empirical results, including a series of robustness checks. Finally, Section 5 offers concluding remarks with policy implications.

\section{I A BRIEF OVERVIEW OF THE LITERATURE}

This paper draws from a major thread of the literature on determinants of sovereign risk. Most studies find empirical support to the theoretical prediction that the level and composition of government debt and other macroeconomic factors have an impact on government bond yields and spreads (Ardagna et al., 2007; Engen \& Hubbard, 2005; Gómez-Puig \& Sosvilla-Rivero, 2014; Hilscher \& Nosbusch, 2010; Kinoshita, 2006; Laubach, 2009). In particular, government's borrowing costs are found to depend on global risk aversion, cross-border spillovers, and country-specific macroeconomic and institutional factors (Afonso, 2010; Afonso \& Nunes, 2015; Attinasi et al., 2009; Beirne \& Fratzscher, 2013; Caceres et al., 2010; de Grauwe et al., 2017; Gödl \& Kleinert, 2016; Poghosyan, 2012).

With regard to CDS spreads, the literature has evolved along two strands. First, the structural approach, developed by Merton (1974) and Black (1976), has defined default as an increasing function of leverage and used asset value and asset volatility to estimate the probability of default. In other words, default risk is modeled by a stochastic process standing for total value of assets of a reference entity such that default happens to be contingent upon the case that total value of entity's assets falls below its liabilities. These models establish a link between the firm's financial status and its credit quality in such a way that the credit event is generated endogenously. Structural models are more appropriate for modeling credit risk of firms as the value of firms' assets can be identified through data sources such as balance sheets. On the other hand, the sovereigns' value of assets is a vaguer concept, although there are attempts in the literature, such as Lehrbass (2000), to approximate it with stock market value. Additionally, a structural model might become complex for a portfolio including many entities since it requires identifying the linkages among the entities in terms of their exposure to different risk factors.

Other studies, on the other hand, analyze sovereign CDS spreads by estimating the impact of macrofinancial factors on credit spreads. This approach has the advantage of providing more intuition on the underlying determinants of sovereign default risk as measured by CDS spreads. The disadvantage of the regression approach, however, is that it may not provide as good a fit, as there is no pricing consistency across maturities when it is estimated for each maturity separately. Focusing on a country's ability and willingness-to-service its debt in a panel of developing countries, Cantor and Packer (1996) find that per capita income, real GDP growth, consumer price inflation, external debt, and default history have significant effects on sovereign credit risk. Likewise, Amato (2005), Baek et al. (2005), and Georgievska et al. (2008) show the link between sovereign risk in developing countries and macroeconomic variables such as the debt-to-GDP ratio, the fiscal balance, the current account position, and international reserves as a share of GDP. Investigating the outcome of the heterogeneous beliefs of the lender and borrower with weekly emerging-market CDS spreads for eight countries, Dieckmann and Gallmeyer (2013) find that macroeconomic shocks are responsible for $40 \%$ of the variation in CDS spreads. Arslanalp and Liao (2014) look at the relationship between government liabilities 
and CDS spreads in 32 countries during the period 2006-2013 and find that a 1\% increase in the contingent liability index raises CDS spreads by 24 basis points in advanced economies and 75 basis points in emerging markets. Focusing on the availability and transparency of fiscal information in a sample of 45 countries over the 2004-2010 period, Peat et al. (2015) find that credit spreads tend to be lower in countries with greater government accountability and transparency. Using daily data for five large emerging markets (Brazil, India, Indonesia, South Africa, and Turkey) during the 2006-2015 period, Yildirim (2016) finds significant variation in CDS spreads due to macroeconomic conditions.

The literature has given an important consideration to cross-country contagion effects. Fender et al. (2012) use daily data on emerging-market CDS spreads over the 2002-2011 period and find a close relationship with global and regional risk premiums, especially during periods of crisis. Similarly, Kim et al. (2015) show that the participation of foreign investors in equity markets has spillover effects on CDS spreads. Analyzing six Latin American countries during the period 2004-2014, Ballester and González-Urteaga (2017) observe cross-border spillover effects arising from credit rating changes in neighboring countries. Some studies also find that commodity markets can influence CDS spreads. Pavlova et al. (2018), for example, analyze the relationship between oil prices and CDS spreads during the period 2008-2015 and find that the volatility of oil prices has a spillover effect on CDS spreads of oil-exporting countries. Wang et al. (2020) show that the impact of oil price shocks on CDS spreads could move beyond oilexporting countries and influence sovereign risk premiums across a broader spectrum of countries.

Research on the financial impact of COVID-19 is nascent, but fast-developing across all asset classes. Heyden and Heyden (2020) and Ramelli and Wagner (2020) focus on equity markets in Europe and the United States and show that news about COVID-19 developments and monetary and fiscal policy measures have driven stock prices. Alfaro et al. (2020) link aggregate equity market returns and unanticipated changes in predicted COVID-19 infections, while Schoenfeld (2020) examines buy-and-hold asset returns and finds a systematic underestimation of the COVID-19 risk in portfolio management. Using high-frequency data, ElFayoumi and Hengge (2020) show that the pandemic and associated policy responses have contributed to the large wave of capital reallocation between markets, asset classes, and industries. Focusing on the COVID-19 impact on corporate bond yields in large European countries, Ettmeier et al. (2020) conclude that the pandemic has affected interest rates across the maturity profile. Using CDS spreads for 26 European countries, Andries et al. (2020) find that a higher number of cases and deaths and public health containment responses result in a significant increase in sovereign risk premiums due to uncertainty among investors. Likewise, Esteves and Sussman (2020) show that greater exposure to the pandemic results in a higher cost of borrowing for emerging markets whereas advanced economies are not affected. The empirical analysis presented in our study contributes to this emergent strand of the literature by investigating the impact of the pandemic on sovereign CDS spreads.

\section{3 | DATA OVERVIEW}

The empirical analysis is based on two different panel data sets: (1) annual observations for 77 countries and territories over the period 2004-2020 and (2) daily observations for 77 countries and territories in the first half of $2020 .{ }^{4}$ We use 5-year CDS spreads as a measure of sovereign default risk, which are obtained from Bloomberg. The main explanatory variable of 
interest is the number of confirmed infectious-disease cases (including COVID-19, Ebola, malaria, SARS, and yellow fever), which are obtained from the WHO and Oxford COVID-19 Government Response Tracker (OxCGRT) databases and normalized by population to put countries on a more comparable scale. ${ }^{5}$ In estimations using daily data, we also introduce the number of deaths caused by COVID-19 per population as an alternative to the number of confirmed COVID-19 cases.

Following the literature, we include a set of control variables, consisting of real GDP per capita, real GDP growth, consumer price inflation, budget balance as a share of GDP, government debt as a share of GDP, current account balance as a share of GDP, international reserves as a share of GDP, trade openness as measured by the ratio of exports and imports to GDP, financial development as measured by domestic credit to the private sector as a share of GDP, and a measure of institutional quality, to capture country characteristics. Country-specific institutional quality is measured by a simple average of the "government effectiveness" and "regulatory quality" indicators from the World Bank's Worldwide Governance Indicators database. Also, to control for common global shocks that may affect sovereign CDS spreads across all countries, we include international oil prices and the volatility implicit in US stock options (VIX index) compiled by the Chicago Board Options Exchange. These variables are assembled from the IMF's International Financial Statistics (IFS) and WEO databases, the World Bank's World Development Indicators (WDI) and Worldwide Governance Indicators (WGI) databases, and the US Federal Reserve Bank of St. Louis. ${ }^{6}$

Descriptive statistics for the variables used in the empirical analysis are presented in Table 1 for the annual data set and in Table 2 for the daily data set. ${ }^{7}$ There is a significant degree of dispersion in sovereign CDS spreads among advanced and emerging-market economies and considerable heterogeneity in the number of confirmed infectious-disease cases per population, as well as in the level and evolution of macroeconomic, financial, and institutional control variables during the sample period. Furthermore, although the spread of COVID-19 cases (or deaths) may appear like a common global shock, there is significant heterogeneity in policy responses across countries and over time.

It is essential to analyze the time-series properties of the data to avoid spurious results by conducting panel unit root tests. The stationarity of all variables is checked by applying the Im et al. (2003) procedure, which is widely used in the empirical literature to conduct a panel unit root test. The results, available upon request, indicate that the variables used in the analysis are stationary after logarithmic transformation if necessary.

\section{4 | EMPIRICAL METHODOLOGY}

Using a strongly balanced panel data set of annual observations comprising 77 advanced and developing countries over the 2004-2020 period, we estimate a standard model with sovereign CDS spreads of 5-year maturity are determined according to the following specification:

$$
C D S_{i t}=\beta+\alpha V i r_{i t}+\gamma X_{i t}+\eta_{i}+\mu_{t}+\varepsilon_{i t}
$$

where $C D S_{i t}$ denotes the logarithm of CDS spreads in country $i$ at time $t$; $V i r_{i t}$ is the logarithm of the number of confirmed cases of infectious diseases (including COVID-19, Ebola, malaria, SARS, and yellow fever) scaled by population; and $X_{i t}$ represents a vector of control variables, including the logarithm of real GDP per capita, real GDP growth, consumer price inflation, budget balance as a share of GDP, government debt as a share of GDP, current account balance 
T A B LE 1 Summary statistics (annual data set)

\begin{tabular}{|c|c|c|c|c|c|}
\hline Variables & Obs. & Mean & SD & Min. & Max. \\
\hline CDS spreads & 1114 & 244.2 & 710.9 & 2 & 11,334 \\
\hline Real GDP per capita & 1343 & $1,85,057$ & $9,85,265$ & 7 & $1,10,00,000$ \\
\hline Real GDP growth & 1264 & 2.6 & 4.7 & -34.9 & 26.2 \\
\hline Consumer price inflation & 1338 & 79.9 & 1911.8 & -4.9 & 65,374 \\
\hline Budget balance & 1341 & -2.2 & 5.9 & -35.4 & 43.3 \\
\hline Government debt & 1320 & 54.5 & 38.9 & 0.1 & 344.3 \\
\hline Current account balance & 1334 & -0.4 & 8.0 & -28.8 & 45.5 \\
\hline Foreign reserves & 1329 & 19.4 & 19.5 & 0.3 & 126.8 \\
\hline Trade openness & 1335 & 87.8 & 51.7 & 19.5 & 442.7 \\
\hline Financial development & 1322 & 76.6 & 50.1 & 0.2 & 309.0 \\
\hline Institutional quality & 1343 & 0.5 & 0.9 & -2.1 & 2.1 \\
\hline Population & 1343 & $7,26,00,000$ & $20,80,00,000$ & $2,90,000$ & $1,40,00,00,000$ \\
\hline VIX & 1343 & 19.0 & 6.8 & 11.1 & 32.5 \\
\hline Oil price & 1343 & 69.8 & 23.1 & 36.2 & 105.0 \\
\hline \multicolumn{6}{|l|}{ Infectious diseases } \\
\hline COVID-19 & 1343 & 6901 & 86,123 & 0 & $25,90,552$ \\
\hline Ebola & 1343 & 0 & 1 & 0 & 20 \\
\hline Malaria & 1343 & $2,21,545$ & $14,42,610$ & 0 & $1,89,00,000$ \\
\hline SARS & 1343 & 0 & 0 & 0 & 0 \\
\hline Yellow fever & 1343 & 4 & 50 & 0 & 1307 \\
\hline
\end{tabular}

Source: Bloomberg; IMF; World Bank; WHO; author's calculations.

TABLE 2 Summary statistics (daily data set)

\begin{tabular}{llllll|} 
Variables & Obs. & Mean & SD & Min. & Max. \\
\hline CDS spreads & 8299 & 335.3 & 1572 & 0 & 28,012 \\
COVID-19 & & & & $26,86,480$ \\
Cases & 12,210 & 35,405 & $1,55,493$ & 0 & $1,28,062$ \\
Deaths & 12,210 & 2188 & 9348 & 0 & 82.7 \\
VIX & 8707 & 34.3 & 16 & 12.1 & 63.3 \\
\hline Oil price & 8629 & 34.4 & 15.4 & -37.00 & 6 \\
\hline
\end{tabular}

Source: Bloomberg; Oxford COVID-19 Government Response Tracker; IMF; authors' calculations.

as a share of GDP, international reserves as a share of GDP, trade openness as measured by the ratio of exports and imports to GDP, financial development as measured by domestic credit to the private sector as a share of GDP, the logarithm of population, and a measure of institutional quality. ${ }^{8}$ The $\eta_{i}$ and $\mu_{t}$ coefficients denote the time-invariant country-specific effects and the 
time effects controlling for common shocks that may affect financial conditions across all countries in a given year, respectively. ${ }^{9} \varepsilon_{i t}$ is an idiosyncratic error term that satisfies the standard assumptions of zero mean and constant variance. To account for possible heteroskedasticity, robust standard errors are clustered at the country level.

To develop a more granular analysis with higher frequency observations and focus exclusively on the recent impact of COVID-19, we estimate the model of sovereign CDS spreads using high-frequency (daily) data for the same sample of 77 countries during the period from January 1, 2019 to June 30, 2020. In addition to the static fixed-effects model, we estimate the dynamic version using the Generalized Method of Moments (GMM) procedure proposed by Arellano and Bover (1995) and Blundell and Bond (1998), which helps correct for estimation biases resulting from the inclusion of the lagged dependent variable, as well as the potential endogeneity of the explanatory variables. The system GMM technique involves constructing two sets of equations, one with first differences of the endogenous and predetermined variables instrumented by suitable lags of their own levels, and one with the levels of the endogenous and predetermined variables instrumented with suitable lags of their own first differences. We apply the one-step version of the system GMM estimator to ensure the robustness of the results, as the standard errors from the two-step variant of the System GMM method are shown to have a downward bias in small samples. ${ }^{10}$

The use of all available lagged levels of the variables in the System GMM estimation leads to a proliferation in the number of instruments, which reduces the efficiency of the estimator in finite samples, and potentially leads to over-fitting. A further issue is that the use of a large number of instruments significantly weakens the Hansen $J$ test of overidentifying restrictions, and so the detection of over-identification is hardest when it is most needed. Conversely, however, restricting the instrument set too much results in a loss of information that leads to imprecisely estimated coefficients. Estimation of such models, therefore, involves a delicate balance between maximizing the information extracted from the data on the one hand and guarding against over-identification on the other. To this end, we follow the strategy suggested by Roodman (2009) to deal with the problem of weak and excessively numerous instruments. We also validate the System GMM identification assumptions by applying a second-order serial correlation test for the residuals and the Hansen $J$ test for the overidentifying restrictions. The values reported for AR(1) and AR(2) are the $p$ values for first- and second-order autocorrelated disturbances in the firstdifferenced equation. As expected, we find that there is high first-order autocorrelation, but no evidence for significant second-order autocorrelation. Similarly, the Hansen $J$ test result indicate the validity of internal instruments used in the dynamic model estimated via the system GMM approach.

\section{5 | ESTIMATION RESULTS}

The empirical analysis is conducted at annual frequency with a data set covering 77 countries during the period 2004-2020 and at daily frequency with the same sample of countries over the period from January 1, 2019, to June 30, 2020. Estimation results present a consistent picture across different specifications, but it is important to note that there is significant heterogeneity in how infectious diseases affect sovereign CDS spreads across countries over time. The magnitude of this effect varies with macroeconomic conditions and institutional strength, which in turn helps determine the effectiveness of policy response to epidemics and pandemics. 


\section{1 | Annual data}

As a baseline, we estimate the equation for the full sample of countries using the standard fixed-effects model and start with a parsimonious specification including only macroeconomic, financial, and institutional variables in Column 1 of Table 3 as a point of reference. We then introduce the number of confirmed infectious-disease cases into the regression in Column 2 for the full sample, as well as for subsamples of advanced and emerging-market economies in Columns 3 and 4, respectively.

With regard to the explanatory power of conventional determinants of sovereign CDS spreads, we obtain estimated elasticities that are broadly consistent with previous studies in the literature. Country-specific economic, financial, and institutional factors have an important role in explaining the variation in CDS spreads. While country characteristics matter everywhere, the magnitude of these effects are found to be greater in emerging-market economies. Our estimation results also confirm that global developments-as captured by the VIX index and crude oil prices-have become increasingly important in determining country risk spreads.

For the main explanatory variable of interest in this study, we find that past epidemics measured by the number of confirmed infectious-disease cases per population do not have a statistically significant effect on sovereign CDS spreads at annual frequency during the period 2004-2020, after controlling for macroeconomic, financial, and institutional factors. Although the coefficient on infectious diseases remains statistically insignificant across all country groups, the results still indicate considerable heterogeneity among advanced and developing countries. These estimations with annual data, however, should be treated with caution, as the movement in sovereign CDS spreads may not be adequately captured at annual frequency and the number of infectious-disease observations during the sample period is limited, especially when we partition the countries into income groups.

We conduct several robustness checks for the full sample of countries: (i) truncating the data set at the 5th and 95th percentiles to exclude potential outliers; (ii) estimating the model for the postglobal financial crisis period (2010-2020); and (iii) using the pseudoPoisson-maximum likelihood (PPML) method to estimate the model for the whole period as well as the postglobal financial crisis period (2010-2020). These results, presented in Appendix Table A2, reaffirm that infectious-disease episodes do not have a significant effect on sovereign CDS spreads when estimated at an annual frequency. It is important note that the coefficient on infectious diseases turns positive in the postglobal financial crisis period, albeit still statistically insignificant. More importantly, however, the COVID-19 pandemic is an unprecedented infectious-disease outbreak in terms of its global scope, at least since the Great Influenza Pandemic of 1918. Therefore, we develop a more granular analysis with daily data focusing exclusively on the impact of COVID-19 on sovereign CDS spreads.

\section{2 | Daily data}

We estimate both the static and dynamic versions of the empirical model with highfrequency data to focus exclusively on the impact of COVID-19 cases on sovereign CDS spreads. Lacking macroeconomic data at daily frequency, we account for concerns associated with omitted variables by including a set of fixed effects and dynamic controls, along with global economic and financial conditions proxied by the VIX index and crude 
T A B L E 3 Infectious diseases and sovereign CDS spreads

\section{Annual data, 2004-2020 (Dependent variable: Log of 5-year CDS spreads)}

\begin{tabular}{|c|c|c|c|c|}
\hline & [1] & [2] & [3] & [4] \\
\hline & All & All & Advanced & Developing \\
\hline \multirow[t]{2}{*}{ Real GDP } & 0.071 & 0.313 & -0.879 & 0.634 \\
\hline & {$[0.242]$} & {$[0.379]$} & [2.228] & {$[0.456]$} \\
\hline \multirow[t]{2}{*}{ Real GDP growth } & -0.004 & -0.004 & 0.018 & -0.004 \\
\hline & [0.008] & [0.013] & [0.029] & {$[0.015]$} \\
\hline \multirow[t]{2}{*}{ Inflation } & 0.015 & 0.018 & 0.002 & 0.020 \\
\hline & {$[0.006]$} & {$[0.011]$} & {$[0.022]$} & {$[0.012]$} \\
\hline \multirow[t]{2}{*}{ Budget balance } & $-0.033^{* * *}$ & -0.019 & -0.011 & -0.007 \\
\hline & [0.009] & [0.010] & [0.014] & {$[0.017]$} \\
\hline \multirow[t]{2}{*}{ Government debt } & $0.024^{* * *}$ & 0.011 & 0.013 & 0.014 \\
\hline & [0.003] & {$[0.005]$} & {$[0.015]$} & {$[0.006]$} \\
\hline \multirow[t]{2}{*}{ Current account balance } & $-0.035^{* * *}$ & -0.010 & -0.002 & -0.013 \\
\hline & {$[0.010]$} & {$[0.011]$} & {$[0.041]$} & {$[0.013]$} \\
\hline \multirow[t]{2}{*}{ Foreign reserves } & 0.009 & 0.009 & 0.012 & 0.013 \\
\hline & {$[0.005]$} & {$[0.007]$} & {$[0.019]$} & {$[0.007]$} \\
\hline \multirow[t]{2}{*}{ Trade openness } & -0.003 & -0.005 & -0.030 & -0.004 \\
\hline & [0.003] & [0.004] & {$[0.034]$} & {$[0.004]$} \\
\hline \multirow[t]{2}{*}{ Financial development } & $0.009^{*}$ & 0.003 & 0.011 & 0.001 \\
\hline & {$[0.003]$} & {$[0.004]$} & [0.006] & {$[0.005]$} \\
\hline \multirow[t]{2}{*}{ Institutional quality } & $-1.157^{* * *}$ & $-1.599 * * *$ & -0.814 & $-1.728^{* * *}$ \\
\hline & [0.293] & {$[0.441]$} & [1.105] & {$[0.478]$} \\
\hline \multirow[t]{2}{*}{ Population } & -0.304 & -1.634 & -1.899 & -2.471 \\
\hline & {$[0.417]$} & [1.219] & [3.828] & [1.464] \\
\hline \multirow[t]{2}{*}{ VIX } & $0.026^{* * *}$ & $0.023^{* * *}$ & 0.004 & $0.024^{* * *}$ \\
\hline & {$[0.003]$} & {$[0.004]$} & {$[0.014]$} & {$[0.004]$} \\
\hline \multirow[t]{2}{*}{ Oil price } & $0.014^{* * *}$ & 0.003 & 0.002 & 0.003 \\
\hline & {$[0.001]$} & {$[0.001]$} & {$[0.006]$} & {$[0.001]$} \\
\hline \multirow[t]{2}{*}{ Infectious diseases } & & -0.053 & -0.005 & -0.067 \\
\hline & & [0.022] & {$[0.050]$} & [0.035] \\
\hline Number of countries & 77 & 74 & 39 & 35 \\
\hline Number of observations & 1045 & 358 & 58 & 294 \\
\hline Fixed effects & Yes & Yes & Yes & Yes \\
\hline Adjusted $R^{2}$ & 0.48 & 0.37 & 0.42 & 0.39 \\
\hline
\end{tabular}

Note: Robust standard errors clustered at the country level are reported in brackets. A constant is included in each regression, but not shown in the table.

$*, * *$, and ${ }^{* * *}$ denote significance at the $10 \%, 5 \%$, and $1 \%$ levels, respectively. 
oil prices. In this setting, we also study how the interaction between COVID-19 infections and containment measures, as reflected in the stringency of the domestic lockdown, affect sovereign CDS spreads.

The results using daily data, presented in Table 4, show that the COVID-19 pandemic has had an economically and statistically significant effect on sovereign CDS spreads across all countries in our sample. The elasticities derived from the baseline specification in Column 2 imply that a 10\% increase in the number of COVID-19 infections leads to 40 basis point increase in CDS spreads. ${ }^{11}$ This adverse impact of the pandemic remains positive and statistically significant when we estimate the model separately for subsamples of advanced and developing countries. Furthermore, the estimated coefficient on COVID-19 infections is found to be larger in the case of advanced economies, which may be a reflection of the greater severity of the pandemic and macrofiscal enormity of the ensuing economic crisis in the developed world, at least during the initial stage of the global coronavirus outbreak. However, the gap between the estimated disease coefficients for advanced and emerging-market economies could also be a result of widespread underreporting in developing countries due to differences in testing availability and institutional capacity (Lau et al., 2020).

The dynamic model with lagged dependent variable to capture persistence over time in sovereign CDS spreads confirm the adverse impact of the COVID-19 pandemic across all countries as well as in sub-samples of advanced and emerging-market economies. These dynamic estimation results via the System GMM approach, presented in Table 5, confirm that the intensity of domestic COVID-19 outbreak is a stronger factor in determining sovereign credit risk as measured by 5 -year CDS spreads, especially in advanced economies. The estimated coefficient on COVID-19 cases reaches 0.062 for the sample of developed countries, compared to 0.042 for emerging-market economies. Finally, we

T A B LE 4 Infectious diseases and sovereign CDS spreads: Static estimations

\begin{tabular}{|c|c|c|c|c|}
\hline \multicolumn{5}{|c|}{ Daily data, January-June 2020 (Dependent variable: Log of 5-year CDS spreads) } \\
\hline & [1] & [2] & [3] & [4] \\
\hline & All & All & Advanced & Developing \\
\hline \multirow[t]{2}{*}{ VIX } & $0.005^{* * *}$ & $0.007^{* * *}$ & $0.007^{* * *}$ & $0.007^{* * *}$ \\
\hline & {$[0.001]$} & [0.008] & {$[0.008]$} & [0.001] \\
\hline \multirow[t]{2}{*}{ Oil price } & $-0.014^{* * *}$ & $-0.008^{* * *}$ & $-0.005^{* * *}$ & $-0.009^{* * *}$ \\
\hline & {$[0.001]$} & {$[0.001]$} & {$[0.001]$} & {$[0.001]$} \\
\hline \multirow[t]{2}{*}{ COVID-19 } & & $0.040^{* * *}$ & $0.044^{* * *}$ & $0.041^{* * *}$ \\
\hline & & {$[0.004]$} & {$[0.005]$} & {$[0.006]$} \\
\hline Number of countries & 75 & 72 & 29 & 43 \\
\hline Number of observations & 8191 & 6379 & 2753 & 3626 \\
\hline Fixed effects & Yes & Yes & Yes & Yes \\
\hline Adjusted $R^{2}$ & 0.58 & 0.62 & 0.70 & 0.52 \\
\hline
\end{tabular}

Note: Robust standard errors clustered at the country level are reported in brackets. A constant is included in each regression, but not shown in the table.

$*, * *$, and ${ }^{* * *}$ denote significance at the $10 \%, 5 \%$, and $1 \%$ levels, respectively. 
TA B LE 5 Infectious diseases and sovereign CDS spreads: Dynamic estimations

\begin{tabular}{|c|c|c|c|c|}
\hline \multicolumn{5}{|c|}{ Daily data, January-June 2020 (Dependent variable: Log of 5-year CDS spreads) } \\
\hline & [1] & [2] & [3] & [4] \\
\hline & All & All & Advanced & Developing \\
\hline \multirow[t]{2}{*}{ Lagged CDS spreads } & $0.422^{* * *}$ & $0.401^{* * *}$ & $0.401^{* * *}$ & $0.401^{* * *}$ \\
\hline & {$[0.041]$} & {$[0.041]$} & [0.041] & {$[0.055]$} \\
\hline \multirow[t]{2}{*}{ VIX } & $0.004^{* * *}$ & $0.004^{* * *}$ & $0.003^{* * *}$ & $0.005^{* * *}$ \\
\hline & {$[0.001]$} & {$[0.001]$} & {$[0.001]$} & {$[0.001]$} \\
\hline \multirow[t]{2}{*}{ Oil price } & -0.001 & -0.000 & 0.000 & -0.000 \\
\hline & {$[0.001]$} & {$[0.001]$} & {$[0.001]$} & {$[0.001]$} \\
\hline \multirow[t]{2}{*}{ COVID-19 } & & $0.050^{* * *}$ & $0.062^{* * *}$ & $0.042^{* * *}$ \\
\hline & & {$[0.006]$} & {$[0.009]$} & {$[0.009]$} \\
\hline Number of countries & 74 & 72 & 29 & 43 \\
\hline Number of observations & 4801 & 3725 & 1617 & 2108 \\
\hline Fixed effects & Yes & Yes & Yes & Yes \\
\hline AR (1), $p$ value & 0.000 & 0.000 & 0.000 & 0.000 \\
\hline AR (2), $p$ value & 0.682 & 0.176 & 0.801 & 0.195 \\
\hline Hansen $J$ test $p$ value & 0.225 & 0.210 & 0.186 & 0.205 \\
\hline
\end{tabular}

Note: Robust standard errors clustered at the country level are reported in brackets. A constant is included in each regression, but not shown in the table.

${ }^{*},{ }^{* *}$, and ${ }^{* * *}$ denote significance at the $10 \%, 5 \%$, and $1 \%$ levels, respectively.

TABLE 6 Infectious diseases and sovereign CDS spreads: Policy interactions

Daily Data, January-June 2020 (Dependent variable: Log of 5-year CDS spreads)

\begin{tabular}{llll}
\hline & All & Advanced & Developing \\
\hline VIX & $0.007^{* * *}$ & $0.007^{* * *}$ & $0.008^{* * *}$ \\
& {$[0.001]$} & {$[0.001]$} & {$[0.001]$} \\
\hline Oil price & $-0.007^{* * *}$ & $-0.005^{* * *}$ & $-0.007^{* *}$ \\
& {$[0.001]$} & {$[0.001]$} & {$[0.001]$} \\
\hline COVID-19 & $0.047^{* * *}$ & $0.048^{* * *}$ & $0.059^{* * *}$ \\
& {$[0.004]$} & {$[0.005]$} & {$[0.007]$} \\
\hline COVID-19 $\times$ Stringency & $-2.839^{*}$ & $-1.185^{*}$ & $-1.258^{*}$ \\
\hline Number of countries & {$[1.381]$} & {$[4.431]$} & {$[5.969]$} \\
\hline Number of observations & 72 & 29 & 43 \\
\hline Fixed effects & 6138 & 2672 & 3466 \\
\hline Adjusted $R^{2}$ & Yes & Yes & Yes \\
\hline
\end{tabular}

Note: Robust standard errors clustered at the country level are reported in brackets. A constant is included in each regression, but not shown in the table.

$*, * *$, and ${ }^{* * *}$ denote significance at the $10 \%, 5 \%$, and $1 \%$ levels, respectively. 
consider the interaction between COVID-19 infections and the stringency of domestic containment measures. ${ }^{12}$ The coefficient on the interaction is negative and statistically significant, which indicates that the impact of COVID-19 infections on sovereign CDS spreads is lower in countries with more stringent containment measures. However, it is an open question whether the relationship between stringent containment measures and CDS spreads remains negative or turn positive over a longer period. While policies aimed at curbing the spread of the disease has helped smooth the shock of the COVID-19 pandemic on sovereign CDS spreads so far, the macrofiscal cost of stringent measures has also contributed to a significant increase in public debt as a share of GDP. Therefore, the erosion of credit worthiness could eventually push the cost of borrowing higher.

\section{6 | CONCLUSION}

This paper investigates the impact of infectious diseases on sovereign CDS spreads, using a panel data set covering of 77 advanced and emerging-market economies from 2004 to 2020 . Estimations at annual frequency indicate that infectious-disease episodes have no discernible effect on market-implied sovereign credit risk, after controlling for macroeconomic and institutional factors. However, our granular analysis using high-frequency (daily) data indicates that the COVID-19 pandemic has had a significant impact on sovereign CDS spreads across all countries. This adverse effect is found to be more pronounced in advanced economies, which may reflect the greater severity of the pandemic and depth of the ensuing economic crisis in these countries, at least during the initial stage of the outbreak. However, it is also important not to overlook the widespread underreporting in developing countries due to bureaucratic and medical constraints.

The pandemic has led to a large-scale fiscal expansion in most countries that is by and large financed by increasing public debt during a period of deep contraction in economic activity. According to the latest IMF estimates, the COVID-19 pandemic pushed government debt levels up by almost 20 percentage points on average in 2020 - almost double the damage during the global financial crisis in 2008. In the short run, while these developments may undermine the quality of sovereign credit, appropriate policy responses to the pandemic, including higher social spending and economically costly containment measures, help deal with the socioeconomic consequences of the pandemic and set the stage for sustainable recovery. Indeed, the empirical analysis presented in this paper shows that more stringent domestic containment measures are associated with lower CDS spreads and thus borrowing costs. Over the medium term, however, the fiscal burden of these efforts could undermine sovereign credit worthiness and eventually push the cost of borrowing higher.

Our findings have two important policy implications. While global macrofinancial conditions and investors' risk appetite are important factors in determining sovereign credit risk, country-specific factors, and in particular fiscal health, are far more critical. When policymakers underestimate fiscal risks, market participants adjust sovereign CDS spreads, particularly for countries with a poor track record in fiscal discipline. This can in turn lead to more elevated debt service costs and higher policy uncertainty. Likewise, there is abundant empirical evidence that poor political stability and weak institutions shape financial markets' perception of sovereign credit risks and thereby contribute to suboptimal investment levels and ultimately lower economic growth (Acemoglu \& Robinson, 2012; Baldacci et al., 2011; Butler \& Fauver, 2006; Camba-Méndez \& Serwa, 2016). 


\section{ACKNOWLEDGEMENTS}

The authors would like to thank the editor, Benn Steil, and two anonymous referees for their insightful comments and guidance that led to marked improvements in the manuscript. An earlier version of this article benefited from comments and suggestions by Katharina Bergant, Marcos de Carvalho Chamon, and Jeromin Zettelmeyer. The views expressed herein are those of the authors and should not be attributed to the IMF, its Executive Board, or its management.

\section{DATA AVAILABILITY STATEMENT}

The data that support the findings of this study are available in the World Health Organization (WHO) and Oxford COVID-19 Government Response Tracker databases, Bloomberg, the IMF's International Financial Statistics (IFS) and World Economic Outlook (WEO) databases, and the World Bank's World Development Indicators (WDI) database.

\section{CONFLICT OF INTERESTS}

The authors declare that there are no conflict of interests.

\section{ENDNOTES}

${ }^{1}$ The latest figures can be found at John Hopkins University's Center for Systems Science and Engineering: https://www.arcgis.com/apps/opsdashboard/index.html\#/bda7594740fd40299423467b48e9ecf6.

${ }^{2}$ Ecuador was the first sovereign to trigger a CDS payment. It happened in November 2008 when Ecuador failed to make an interest payment, which was considered as a trigger event. It was decided that investors were paid the full amount $(68.625 \%$ of the gross notional value of the CDS contracts that they had purchased since the recovery rate was equal to $31.375 \%$ ).

${ }^{3}$ To capture the impact of COVID-19 at annual frequency, we use the data as of June 30, 2020 and macroeconomic projections from the IMF's World Economic Outlook (WEO) database.

${ }^{4}$ The list of advanced and emerging-market economies is presented in Appendix Table A1.

${ }^{5}$ The SARS epidemic occurred outside the sample period (2004-2020), and the number of Ebola cases/deaths were limited a handful of countries in the sample.

${ }^{6}$ The list of variables, measurement units and data sources is presented in Appendix Table A3.

${ }^{7}$ Summary statistics for country groups are presented in Appendix Table A4.1 for advanced economies and Appendix Table A4.2 for emerging markets.

${ }^{8}$ Data limitations prevent estimating the model with quarterly data. Thereby, this paper presents the estimations with annual data as a point of reference for a broader set of infectious diseases.

${ }^{9}$ We remove time fixed effects in specifications with global variables (i.e., the VIX index and crude oil prices).

${ }^{10}$ The results remain broadly unchanged when we use the two-step version of the system GMM estimator.

${ }^{11}$ The estimation results remain unchanged when we use the number of deaths caused by COVID-19 instead of the number of COVID-19 cases.

${ }^{12}$ The OxCGRT database collects information on several different common policy responses that governments have taken to respond to the COVID-19 pandemic on indicators such as school closures and travel restrictions and builds a composite measure of policy stringency that is rescaled to a value from 0 to $100(100=$ strictest $)$.

\section{ORCID}




\section{REFERENCES}

Acemoglu, D., \& Robinson, J. (2012). Why nations fail: The origins of power, prosperity, and poverty. Crown. Afonso, A. (2010). Long-term government bond yields and economic forecasts: Evidence for the EU. Applied Economics Letters, 17, 1437-1441.

Afonso, A., \& Nunes, A. (2015). Economic forecasts and sovereign yields. Economic Modelling, 2015, 44, 319-326. Alfaro, L., Chari, A., Greenland, A., \& Schott, P. (2020). Aggregate and Firm-Level Stock Returns During Pandemics (NBER working Paper No. 26950). National Bureau of Economic Research.

Amato, J. (2005). Risk aversion and risk premia in the CDS market. BIS Quarterly Review, 5, 55-68.

Andries, A., Ongena, S., \& Sprincean, N. (2020). The COVID-19 pandemic and sovereign bond risk (SFI Working Paper No. 20-42). Swiss Finance Institute.

Ardagna, S., Caselli, F., \& Lane, T. (2007). Fiscal discipline and the cost of public debt service: Some estimates for OECD countries. The B.E. Journal of Macroeconomics, 7, 1-35.

Arellano, M., \& Bover, O. (1995). Another look at the instrumental variable estimation of error-components models. Journal of Econometrics, 68, 29-51.

Arslanalp, S., \& Liao, Y. (2014). Banking sector contingent liabilities and sovereign risk. Journal of Empirical Finance, 29, 316-330.

Attinasi, M., Checherita-Westphal, C., \& Nickel, C. (2009). What Explains the Surge in Euro Area Sovereign Spreads During the Financial Crisis of 2007-09? (ECB Working Paper No. 1131). European Central Bank.

Baek, I.-M., Bandopadhyaya, A., \& Du, C. (2005). Determinants of market-assessed sovereign risk: economic fundamentals or market risk appetite? Journal of International Money and Finance, 24, 533-548.

Baldacci, E., Gupta, S., \& Mati, A. (2011). Political and fiscal risk determinants of sovereign spreads in emerging markets. Review of Development Economics, 15, 251-263.

Ballester, L., \& González-Urteaga, A. (2017). How credit ratings affect sovereign credit risk: Cross-border evidence in Latin American emerging markets. Emerging Markets Review, 30, 200-214.

Beirne, J., \& Fratzscher, M. (2013). The pricing of sovereign risk and contagion during the European sovereign debt crisis. Journal of International Money and Finance, 34, 60-82.

Berndt, A., \& Obreja, I. (2010). Decomposing European CDS returns. Review of Finance, 14, 189-233.

Black, F. (1976). The pricing of commodity contracts. Journal of Financial Economics, 3, 167-179.

Butler, A., \& Fauver, L. (2006). Institutional environment and sovereign credit ratings. Financial Management, $35,53-79$.

Caceres, C., Guzzo, V., \& Segoviano, M. (2010). Sovereign spreads: Global risk aversion, contagion or fundamentals? (IMF Working Paper No. 10/120). International Monetary Fund.

Camba-Méndez, G., \& Serwa, D (2016). Market perception of sovereign credit risk in the Euro area during the financial crisis. North American Journal of Economics and Finance, 37, 168-189.

Canova, F., \& Ciccarelli, M. (2013). Panel vector autoregressive models: A survey (ECB Working Paper No. 1507). European Central Bank.

Cantor, R., \& Packer, F. (1996). Determinants and impact of sovereign credit ratings. Economic Policy Review, 2, 37-53.

Dieckmann, S., \& Gallmeyer, M. (2013). Rare event risk and emerging market debt with heterogeneous beliefs. Journal of International Money and Finance, 33, 163-187.

ElFayoumi, K., \& Hengge, M. (2020). Capital markets, COVID-19 and policy measures. COVID Economics, 45, $32-64$.

Engen, E., \& Hubbard, R. (2005). Federal government debt and interest rates. In M. Gertler, \& K. Rogoff (Eds.), NBER Macroeconomics Annual 2004. MIT Press.

Esteves, R., \& Sussman, N. (2020). Corona spreads, Mimeo. Geneva: Graduate Institute of International and Development Studies.

Ettmeier, S., Kim, C., \& Kriwoluzky, A. (2020). Financial market participants expect the coronavirus pandemic to have long-lasting economic impact in Europe. DIW Weekly Report, 10, 243-250.

Fender, I., Hayo, B., \& Neuenkirch, M. (2012). Daily pricing of emerging market sovereign CDS before and during the global financial crisis. Journal of Banking \& Finance, 36, 2786-2794.

Georgievska, A., Georgievska, L., Stojanovic, A., \& Todorovic, N. (2008). Sovereign rescheduling probabilities in emerging markets: A comparison with credit rating agencies' ratings. Journal of applied statistics, 35, 1031-1051. 
Grauwe, P., Ji, Y., \& Macchiarelli, C. (2017). Fundamentals versus market sentiments in the euro bond markets: Implications for QE (LSE Research on Economics No. 85127). London School of Economics and Political Science.

Gómez-Puig, M., \& Sosvilla-Rivero, S. (2014). Causality and contagion in EMU sovereign debt markets. International Review of Economics \& Finance, 33, 12-27.

Gödl, M., \& Kleinert, J. (2016). Interest rate spreads in the eurozone: Fundamentals or sentiments? Review of World Economics, Vl, 152, 449-475.

Hassan, M., Ngene, G., \& Yu, J.-S. (2015). Credit default swaps and sovereign debt markets. Economic Systems, $39,240-252$.

Heyden, K., \& Heyden, T. (2020). Market reactions to the arrival and containment of COVID-19: An event study. Working Paper. University of Giessen.

Hilscher, J., \& Nosbusch, Y. (2010). Determinants of sovereign risk: Macroeconomic fundamentals and the pricing of sovereign debt. Review of Finance, 14, 235-262.

Hull, J., Predescu, M., \& White, A. (2004). The relationship between credit default swap spreads, bond yields, and credit rating announcements. Journal of Banking \& Finance, 28, 2789-2811.

Im, K., Pesaran, M., \& Shin, Y. (2003). Testing for unit roots in heterogeneous panels. Journal of Econometrics, 115, 53-74.

Kim, B.-H., Kim, H., \& Lee, B.-S. (2015). Spillover effects of the U.S. financial crisis on financial markets in emerging Asian countries. International Review of Economics and Finance, 39, 192-210.

Kinoshita, N. (2006). Government debt and long-term interest rates (IMF Working Paper No. 06/63). International Monetary Fund.

Lau, H., Khosrawipour, T., Kocbach, P., Ichii, H., Bania, J., \& Khosrawipoura, V. (2020). Evaluating the massive underreporting and undertesting of COVID-19 cases in multiple global epicenters. Pulmonology, 2020.

Laubach, T. (2009). New evidence on the interest rate effects of budget deficits and debt. Journal of the European Economic Association, 7, 858-885.

Lehrbass, F. (2000). A simple approach to country, Risk: Measuring Risk in Complex Stochastic Systems. Springer. Merton, R. (1974). On the pricing of corporate debt: The risk structure of interest rates. Journal of Finance, 29, 449-470.

Nickell, S. (1981). Biases in dynamic models with fixed effects. Econometrica, 49, 1417-1426.

Pavlova, I., Boyrie, M., \& Parhizgari, A. (2018). A dynamic spillover analysis of crude oil effects on the sovereign credit risk of exporting countries. Quarterly Review of Economics and Finance, 68, 10-22.

Peat, M., Svec, J., \& Wang, J. (2015). The effects of fiscal opacity on sovereign credit spreads. Emerging Markets Review, 24, 34-45.

Poghosyan, T. (2012). Long-run and short-run determinants of sovereign bond yields in advanced economies (IMF Working Paper No. 12/271). International Monetary Fund.

Ramelli, S., \& Wagner, A. (2020). Feverish stock price reactions to COVID-19 (Swiss Finance Institute Research Paper No. 20-12). Swiss Finance Institute.

Ramos-Francia, M., \& Rangel, J. (2012). Revisiting the effects of country specific fundamentals on sovereign default risk. Economics Bulletin, 32, 3008-3016.

Roodman, D. (2009). How to Do xtabond2: An introduction to difference and system GMM in stata. Stata Journal, 9, 86-136.

Schoenfeld, J. (2020). The invisible risk: Pandemics and the financial markets (Tuck School of Business Working Paper No. 3567249). Dartmouth College.

Wang, J., Sun, X., \& Li, J. (2019). How do sovereign credit default swap spreads behave under extreme oil price movements? Evidence from G7 and BRICS countries. Finance Research Letters, 34, 1-10.

Yildirim, Z. (2016). Global financial conditions and asset markets: Evidence from fragile emerging economies. Economic Modelling, 57, 208-220.

How to cite this article: Cevik, S., \& Öztürkkal, B. (2021). Contagion of fear: Is the impact of COVID-19 on sovereign risk really indiscriminate? International Finance, 24, 134-154. https://doi.org/10.1111/infi.12397 


\section{APPENDIX}

TABLE A1 List of countries

\begin{tabular}{|c|c|c|c|c|c|}
\hline 1 & Algeria & 27 & Hungary & 53 & Philippines \\
\hline 2 & Argentina & 28 & Iceland & 54 & Poland \\
\hline 3 & Australia & 29 & India & 55 & Portugal \\
\hline 4 & Austria & 30 & Indonesia & 56 & Qatar \\
\hline 5 & Bahrain & 31 & Ireland & 57 & Romania \\
\hline 6 & Belgium & 32 & Italy & 58 & Russia \\
\hline 7 & Brazil & 33 & Israel & 59 & Rwanda \\
\hline 8 & Bulgaria & 34 & Japan & 60 & Saudi arabia \\
\hline 9 & Canada & 35 & Kazakhstan & 61 & Serbia \\
\hline 10 & Chile & 36 & Korea & 62 & Slovak Republic \\
\hline 11 & China & 37 & Kuwait & 63 & Slovenia \\
\hline 12 & Colombia & 38 & Latvia & 64 & South africa \\
\hline 13 & Costa rica & 39 & Lebanon & 65 & Spain \\
\hline 14 & Croatia & 40 & Lithuania & 66 & Sri Lanka \\
\hline 15 & Cyprus & 41 & Malaysia & 67 & Sweden \\
\hline 16 & Czech Republic & 42 & Mexico & 68 & Switzerland \\
\hline 17 & Denmark & 43 & Mongolia & 69 & Thailand \\
\hline 18 & Egypt & 44 & Morocco & 70 & Tunisia \\
\hline 19 & El Salvador & 45 & Netherlands & 71 & Turkey \\
\hline 20 & Estonia & 46 & New zealand & 72 & Ukraine \\
\hline 21 & Finland & 47 & Nicaragua & 73 & United states \\
\hline 22 & France & 48 & Nigeria & 74 & United kingdom \\
\hline 23 & Germany & 49 & Norway & 75 & Uruguay \\
\hline 24 & Greece & 50 & Pakistan & 76 & Venezuela \\
\hline 25 & Guatemala & 51 & Panama & 77 & Vietnam \\
\hline 26 & Hong Kong SAR & 52 & Peru & & \\
\hline
\end{tabular}


TABLE A2 Infectious diseases and sovereign CDS spreads: Robustness checks

\section{Annual data, 2004-2020 (Dependent variable: Log of 5-year CDS spreads)}

\begin{tabular}{|c|c|c|c|c|}
\hline & \multirow[b]{2}{*}{ Truncated sample } & \multirow[b]{2}{*}{ Post-GFC period } & \multicolumn{2}{|c|}{ PPML estimator } \\
\hline & & & 2004-2020 & Post-GFC period \\
\hline \multirow[t]{2}{*}{ Real GDP } & 0.109 & $-1.486^{* * *}$ & 0.003 & 0.004 \\
\hline & {$[0.403]$} & {$[0.438]$} & {$[0.003]$} & {$[0.004]$} \\
\hline \multirow[t]{2}{*}{ Real GDP growth } & 0.009 & 0.005 & 0.005 & $0.009^{* *}$ \\
\hline & {$[0.012]$} & {$[0.010]$} & {$[0.003]$} & {$[0.003]$} \\
\hline \multirow[t]{2}{*}{ Inflation } & $0.030^{*}$ & 0.019 & $0.006^{*}$ & 0.005 \\
\hline & {$[0.011]$} & {$[0.010]$} & {$[0.002]$} & {$[0.002]$} \\
\hline \multirow[t]{2}{*}{ Budget balance } & -0.011 & -0.016 & -0.005 & $-0.006^{*}$ \\
\hline & {$[0.011]$} & {$[0.010]$} & {$[0.014]$} & {$[0.002]$} \\
\hline \multirow[t]{2}{*}{ Government debt } & $0.015^{* *}$ & 0.007 & $0.001^{* * *}$ & $0.001^{* * *}$ \\
\hline & {$[0.003]$} & {$[0.004]$} & {$[0.000]$} & {$[0.000]$} \\
\hline \multirow[t]{2}{*}{ Current account balance } & -0.004 & -0.021 & 0.002 & 0.003 \\
\hline & {$[0.011]$} & {$[0.009]$} & {$[0.003]$} & {$[0.003]$} \\
\hline \multirow[t]{2}{*}{ Foreign reserves } & 0.012 & $0.015^{*}$ & -0.001 & -0.002 \\
\hline & {$[0.007]$} & {$[0.006]$} & {$[0.001]$} & {$[0.001]$} \\
\hline \multirow[t]{2}{*}{ Trade openness } & -0.007 & -0.004 & $-0.001^{* *}$ & -0.001 \\
\hline & {$[0.004]$} & {$[0.002]$} & {$[0.000]$} & {$[0.000]$} \\
\hline \multirow[t]{2}{*}{ Financial development } & 0.004 & 0.008 & 0.000 & 0.000 \\
\hline & {$[0.004]$} & {$[0.005]$} & {$[0.000]$} & {$[0.000]$} \\
\hline \multirow[t]{2}{*}{ Institutional quality } & $-1.166^{* *}$ & $-0.557^{* *}$ & $-0.237^{* * *}$ & $-0.228^{* * *}$ \\
\hline & {$[0.293]$} & {$[0.303]$} & {$[0.024]$} & {$[0.021]$} \\
\hline \multirow{2}{*}{ Population } & -1.067 & -0.272 & $-0.048^{* * *}$ & $-0.047^{* * *}$ \\
\hline & {$[0.417]$} & {$[1.190]$} & {$[0.010]$} & {$[0.012]$} \\
\hline \multirow[t]{2}{*}{ VIX } & $0.021^{* * *}$ & 0.002 & $0.004^{* * *}$ & 0.001 \\
\hline & {$[0.004]$} & {$[0.004]$} & {$[0.014]$} & {$[0.001]$} \\
\hline \multirow[t]{2}{*}{ Oil price } & 0.002 & $-0.003^{*}$ & 0.001 & 0.000 \\
\hline & {$[0.001]$} & {$[0.001]$} & {$[0.000]$} & {$[0.000]$} \\
\hline \multirow[t]{2}{*}{ Infectious diseases } & -0.048 & 0.008 & -0.004 & 0.002 \\
\hline & {$[0.022]$} & {$[0.015]$} & {$[0.004]$} & [0.004] \\
\hline Number of countries & 72 & 74 & 74 & 74 \\
\hline Number of observations & 342 & 277 & 358 & 277 \\
\hline Fixed effects & Yes & Yes & Yes & Yes \\
\hline
\end{tabular}




\section{TABLE A 2 (Continued)}

\begin{tabular}{|c|c|c|c|c|}
\hline & \multirow[b]{2}{*}{ Truncated sample } & \multirow[b]{2}{*}{ Post-GFC period } & \multicolumn{2}{|c|}{ PPML estimator } \\
\hline & & & 2004-2020 & Post-GFC period \\
\hline Adjusted $\mathrm{R}^{2}$ & 0.3368 & 0.4125 & 0.4263 & 0.4263 \\
\hline
\end{tabular}

Note: Robust standard errors clustered at the country level are reported in brackets. A constant is included in each regression, but not shown in the table.

$*, * *$, and $* * *$ denote significance at the $10 \%, 5 \%$, and $1 \%$ levels, respectively.

TABLE A3 List of variables and sources (yearly)

\begin{tabular}{|c|c|c|}
\hline Variables & Definition & Source \\
\hline CDS spreads & 5-year CDS spread & Bloomberg \\
\hline Real GDP per capita & Real GDP per capita in USD & WDI \\
\hline Real GDP growth & Annual growth of real GDP $\%$ & WDI \\
\hline Consumer price inflation & Annual consumer price inflation $\%$ & WDI \\
\hline Budget balance & Budget balance as a share of GDP & WDI \\
\hline Government debt & Government debt as a share of GDP & WDI \\
\hline Current account balance & Current account balance as a share of GDP & WDI \\
\hline Foreign reserves & $\begin{array}{l}\text { Foreign reserves international reserves as a share } \\
\text { of GDP }\end{array}$ & WDI \\
\hline Trade openness & Ratio of exports and imports to GDP & WDI \\
\hline Financial development & $\begin{array}{l}\text { Domestic credit to the private sector as a share } \\
\text { of GDP }\end{array}$ & WDI \\
\hline Institutional quality & $\begin{array}{l}\text { Average of "government effectiveness" and } \\
\text { "regulatory quality" indicators }\end{array}$ & WDI \\
\hline Population & Country population, number & WDI \\
\hline VIX & $\begin{array}{l}\text { Implied volatility of S\&P 500, CBOE Volatility } \\
\text { Index }\end{array}$ & $\begin{array}{l}\text { Federal Reserve Bank } \\
\text { of St. Louis }\end{array}$ \\
\hline Oil price & Oil price, USD per Barrel & $\begin{array}{l}\text { Federal Reserve Bank } \\
\text { of St. Louis }\end{array}$ \\
\hline Stringency index & Index from 0 to $100(100=$ strictest $)$ & OxCGRT \\
\hline \multicolumn{3}{|l|}{ Infectious diseases } \\
\hline COVID-19 & Total number & OxCGRT \\
\hline Ebola & Total number & WHO \\
\hline Malaria & Total number & WHO \\
\hline SARS & Total number & WHO \\
\hline Yellow fever & Total number & WHO \\
\hline
\end{tabular}

Source: Bloomberg; IMF; World Bank; WHO; OXCGRT. 
T A B LE A4.1 Summary statistics by country group: Advanced

\begin{tabular}{|c|c|c|c|c|c|}
\hline Variables & Obs. & Mean & SD & Min. & Max. \\
\hline CDS spreads & 481 & 128.7 & 563 & 2 & 11,334 \\
\hline Real GDP per capita & 544 & 64,436 & $2,76,687$ & 16 & $18,00,000$ \\
\hline Real GDP growth & 512 & 1.4 & 4 & -15 & 25 \\
\hline Consumer price inflation & 544 & 1.9 & 2 & -2 & 15 \\
\hline Budget balance & 544 & -2.1 & 5 & -32 & 19 \\
\hline Government debt & 544 & 65.8 & 45 & 0 & 268 \\
\hline Current account balance & 544 & 0.3 & 6 & -23 & 16 \\
\hline Foreign reserves & 544 & 14.9 & 22 & 0 & 127 \\
\hline Trade openness & 544 & 102.4 & 65 & 24 & 443 \\
\hline Financial development & 544 & 112.8 & 48.18 & 0.19 & 308.98 \\
\hline Institutional quality & 544 & 1.4 & 0 & 0 & 2 \\
\hline Population & 544 & $3,14,00,000$ & $5,84,00,000$ & $2,90,000$ & $33,00,00,000$ \\
\hline Infectious diseases & 544 & & & & \\
\hline COVID-19 & 544 & 7850 & $1,13,430$ & 0 & $25,90,552$ \\
\hline Ebola & 544 & 0 & 0 & 0 & 4 \\
\hline Malaria & 544 & 0 & 0 & 0 & 0 \\
\hline SARS & 0 & 0 & 0 & 0 & 0 \\
\hline Yellow fever & 0 & 0 & 0 & 0 & 5 \\
\hline
\end{tabular}

Source: Bloomberg; IMF; World Bank; WHO; OXCGRT; author's calculations. 
T A B LE A4.2 Summary statistics by country group: Developing

\begin{tabular}{|c|c|c|c|c|c|}
\hline Variables & Obs. & Mean & SD & Min. & Max. \\
\hline CDS spreads & 633 & 332.0 & 794 & 13 & 11,297 \\
\hline Real GDP per capita & 799 & $2,66,930$ & $12,50,551$ & 0 & $1,10,00,000$ \\
\hline Real GDP growth & 752 & 3.4 & 5 & -35 & 26 \\
\hline Consumer price inflation & 794 & 133.4 & 2481 & -5 & 65,374 \\
\hline Budget balance & 797 & -2.2 & 7 & -35 & 43 \\
\hline Government debt & 776 & 46.6 & 32 & 2 & 344 \\
\hline Current account balance & 790 & -0.8 & 9 & -29 & 45 \\
\hline Foreign reserves & 785 & 22.6 & 16 & 0 & 109 \\
\hline Trade openness & 791 & 77.7 & 36 & 20 & 195 \\
\hline Financial development & 792 & 52.4 & 34 & 1 & 161 \\
\hline Institutional quality & 799 & -0.1 & 1 & -2 & 1 \\
\hline Population & 799 & $10,10,00,000$ & $26,10,00,000$ & $7,20,000$ & $1,40,00,00,000$ \\
\hline \multicolumn{6}{|l|}{ Infectious diseases } \\
\hline COVID-19 & 799 & 6256 & 60,971 & 0 & $13,68,195$ \\
\hline Ebola & 799 & 0 & 1 & 0 & 20 \\
\hline Malaria & 799 & $3,72,384$ & $18,55,692$ & 0 & $1,89,00,000$ \\
\hline SARS & 799 & 0 & 0 & 0 & 0 \\
\hline Yellow fever & 799 & 6 & 65 & 0 & 1307 \\
\hline
\end{tabular}

Source: Bloomberg; IMF; World Bank; WHO; OXCGRT; author's calculations. 